\title{
Implementasi Deep Learning Untuk Rekomendasi Aplikasi E-learning Yang Tepat Untuk Pembelajaran Jarak Jauh
}

\author{
Wowon Priatna ${ }^{1,{ }^{*},}$ Rakhmat Purnomo ${ }^{1}$, Tri Dharma Putra ${ }^{1}$ \\ ${ }^{1}$ Fakultas IImu Komputer; Universitas Bhayangkara Jakarta Raya; Jl. Perjuangan 81, Marga \\ Mulya, Bekasi Utara; 02188955882; e-mail: wowon.priatna@dsn.ubharajaya.ac.id, \\ rakhmat.purnomo@dsn.ubharajaya.ac.id, tridharma.putra@dsn.ubharajaya.ac.id \\ * Korespondensi: e-mail: wowon.priatna@dsn.ubharajaya.ac.id \\ Submitted: 26/05/2021; Revised: 07/06/2021; Accepted: 11/06/2021; Published: 30/09/2021
}

\begin{abstract}
The purpose of this study is to recommend e-learning applications that are appropriate for use in online learning in college environments. The large number of e-learning platforms used by lecturers for online lecture activities results in students being forced to use several e-learning applications depending on the lecturer who teaches the courses taken, for the university also finally gives lecturers policies for distance learning reports each finished giving the material. In this study the data collection method began by taking data from the faculty to find out which elearning applications were widely used by lecturers, then distributing questionnaires to students and lecturers who used the e-learning application to measure the E-learning application with the e-learning criteria. Appropriate. The data is then processed into a dataset. The algorithm used in implementing deep learning is Artificial Neural Network (ANN). For the implementation of ANN, 27 variables were determined from the e-learning criteria and 1 target. In this ANN stage, prediction was used with classifications based on preparation, training, learning, evaluation and prediction using the python programming. The results obtained in this study that the Moodle application gets the highest score with an accuracy of $97 \%$ to be used as a recommendation for e-learning applications that are appropriate for universities to conduct online lectures.
\end{abstract}

Keywords: Artificial Neural Network, Deep Learning, E-learning, Online Teaching, Python

\begin{abstract}
Abstrak
Tujuan penelitian ini adalah untuk rekomendasi aplikasi e-learning yang tepat untuk digunakan dalam pembelajaran online dilingkungan perguruan tinggi. Banyaknya platform e-learning yang digunakan oleh dosen-dosen untuk kegiatan kuliah online berakibat mahasiswa dalam belajar terpaksa menggunakan beberapa aplikasi e-learning tergantung dari dosen yang mengajar mata kuliah yang diambil, untuk pihak universitas juga akhirnya memberikan kebijakan dosendosen untuk laporan pembelajaran jarak setiap selesai memberikan materi. Dalam penelitian ini metode pengumpulan data dimulai dengan mengambil data dari fakultas untuk mengetahui aplikasi e-learning yang banyak digunakan oleh para dosen, selanjutnya membagikan kuisioner kepada mahasiswa dan dosen yang menggunakan aplikasi e-learning untuk mengukur aplikasi e-leaning tersebut dengan kriteria e-learning yang sesuai. Data kemudian diolah dijadikan dataset. Algoritma yang digunakan dalam implementasi deep learning ini adalah Artificial Neural Network (ANN). Untuk implementasi ANN ditentukan 27 variable yang didapat dari kriteria elearning dan 1 target, dalam tahapan ANN ini menggunakan prediksi dengan klasifikasi berdasarkan preposesing training, learning, evaluation dan prediction dengan menggunakan pemograman python. Hasilnya yang didapat penelitian ini aplikasi moodle mendapatkan nilai tertinggi dengan akurasi $97 \%$ untuk dijadikan rekomendasi aplikasi e-learning yang tepat digunakan untuk perguruan tinggi dalam melakukan perkuliahan online.
\end{abstract}


Kata kunci: Artificial Neural Network, Deep Learning, E-learning, Online Teaching, Python

\section{Pendahuluan}

Dengan perkembangan teknologi di seluruh dunia dan dengan booming akses informasi, pembelajaran jarak jauh telah menjadi lebih populer karena memungkinkan individu untuk mempelajari keterampilan baru tanpa kehadiran mentor secara fisik dalam mengajar. Pembelajaran jarak jauh merupakan bagian dari proses e-learning karena memungkinkan orang untuk berbagi pengetahuan meskipun ada batasan dan batasan geografis. Seperti disebutkan sebelumnya, e-learning dapat didefinisikan sebagai akses ke kurikulum pendidikan di luar kelas tradisional dengan memanfaatkan teknologi elektronik(Moubayed, Injadat, Nassif, Lutfiyya, \& Shami, 2018).

Sejak diberlakukannya larangan kegiatan belajar mengajar di sekolah, diuniversitas dan sejenisnya oleh mendikbud untuk mencegah penularan virus covid 19 maka dengan itu diberlakukan kuliah daring. Sekolah dan universitas dalam melakukan daring atau e-learning memutuskan untuk menggunakan aplikasi e-learning baik yang gratis, berbayar dipasaran atau membuat aplikasi e-learning sendiri.

Untuk memilih aplikasi e-learning yang tepat untuk mendukung pembelajaran harus memperhatikan dari fitur-fitur, kecepatan mengakses aplikasi, kemudahan, user friendly, support multi platform. Maka itu perlu di lakukan klasifikasi aplikasi e-learning yang tepat untuk mendukung kegiatan pembelajaran. Salah satu metode untuk melakukan klasifikasi adalah menggunakan teknik deep learning. Deep Learning dapat memberikan rekomendasi klasifikasi berdasarkan input output pembelajaran (Liu \& WU, 2017). Deep learning dapat memberikan klasifikasi dari model integrase pembelajaran(Fakhfakh, Ben, \& Ben, 2017)

Deep learning untuk klasifikasi gambar hewan menggunakan(Chauhan \& Ram, 2018), prediksi kesehatan jembatan menggunakan algoritma Artifcial Neural Network jenis deep learning (Reza, 2017). Deep learning dapat digunakan untuk rekomendasi system(Shiddieqy, Hariadi, \& Adiono, 2017), rekomendasi tantangan saat ini(Fakhfakh et al., 2017). Deep learning dapat digunakan untuk prediksi perkembangan e-learning dimasa depan(Muniasamy \& Alasiry, 2020). Deep learning dapat digunakan juga untuk prediksi hasil belajar dilingkungan pendidikan tinggi.

Dari latar belakang masalah dan dari beberapa penelitan diatas maka tujuan dalam penelitian ini adalah untuk memprediksi aplikasi e-learning yang tepat sebagai rekomendasi untuk perkuliahan jarak jauh di lingkungan Perguruan Tinggi.

\section{Metode Penelitian}

Terdapat beberapa tahapan dalam melakukan implementasi deep learning terhadap rekomendasi aplikasi e-learning yang tepat untuk pendidikan jarak jauh ditunjukkan pada gambar 1. 


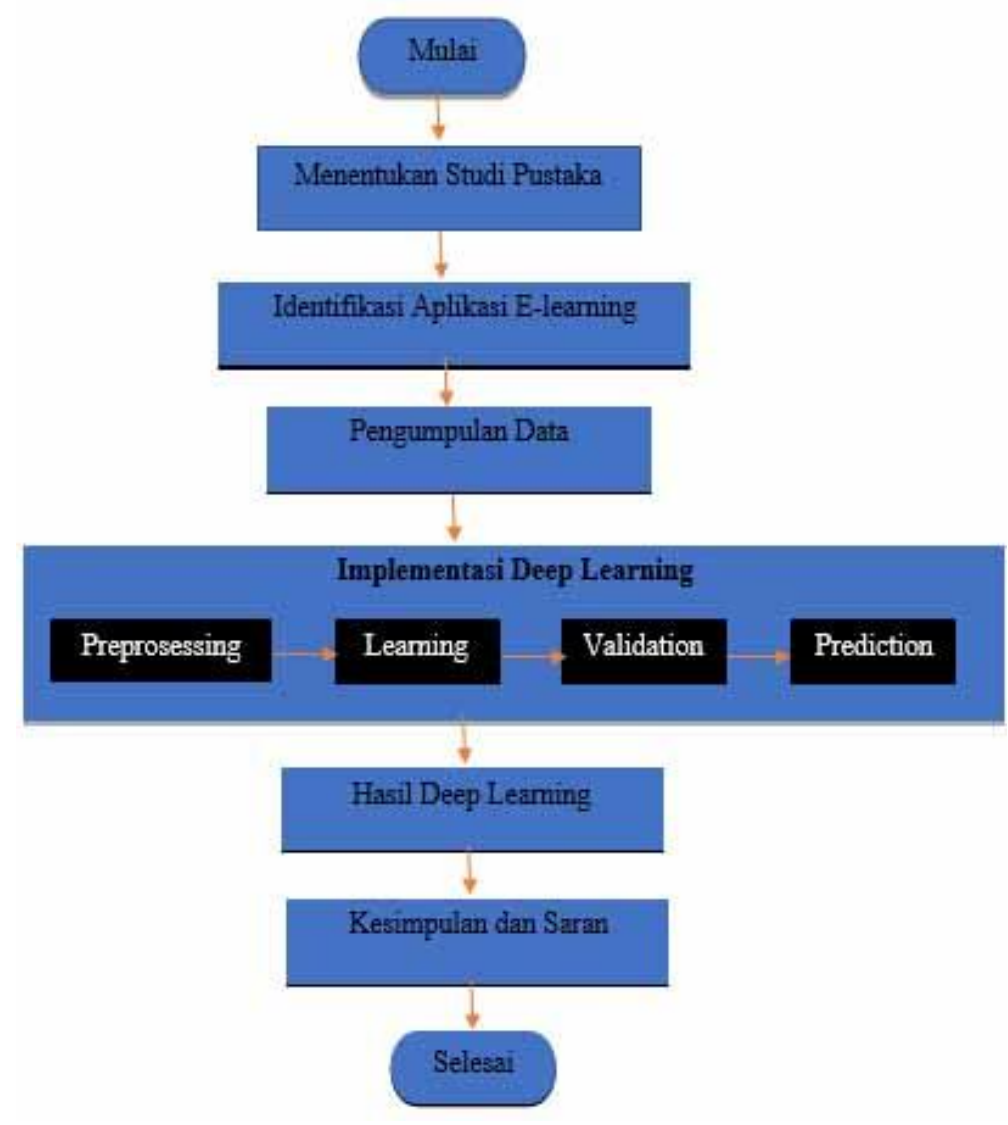

Sumber: Hasil Pengolahan Data (2021)

Gambar 1. Tahapan Penelitian

\subsection{Menentukan studi pustaka}

Menentukan Studi pustaka untuk mendapatkan referensi untuk penerapan deep learning untuk mendapatkan algoritma yang tepat untuk memberikan rekomendasi e-learning untuk pengguna

\subsection{Indentifikasi Aplikasi E-learning}

Identfikasi e-learning adalah indentifikasi aplikasi e-learning yang digunakan dilingkungan universitas oleh dosen-dosen dalam melakukan pembelajaran online di masa pademi covid 19. Indentifikasi aplikasi e-learning digunakan 4 jenis aplikasi yang paling banyak digunakan dalam pembelajaran online diataranya moodle, google classroom, slack dan edmodo.

\subsection{Pengumpulan Data}

Teknik pengumpulan data yang digunakan dalam penelitian ini adalah membagikan kuisioner dengan responden dosen dan Mahasiswa Fakultas IImu Komputer Universitas Bhayangkara Jakarta Raya.

\subsection{Implementasi Deep Learning}

Implementasi deep learning adalah proses untuk mengolah data untuk prediksi aplikasi e-learning yang tepat menggunakan algoritma artificial neural network. Dimana prediksi dilakukan berdasarkan data yang telah didapat dan bagaimana system dapat 
mengklasifikasikannya. Tahapan prediksi menggunakan kelasifikasi diantaranya Preprocessing, Learning, Evaluation, Prediction (Raschka, 2015), tahapan klasifikasi ditunjukan oleh gambar 2.

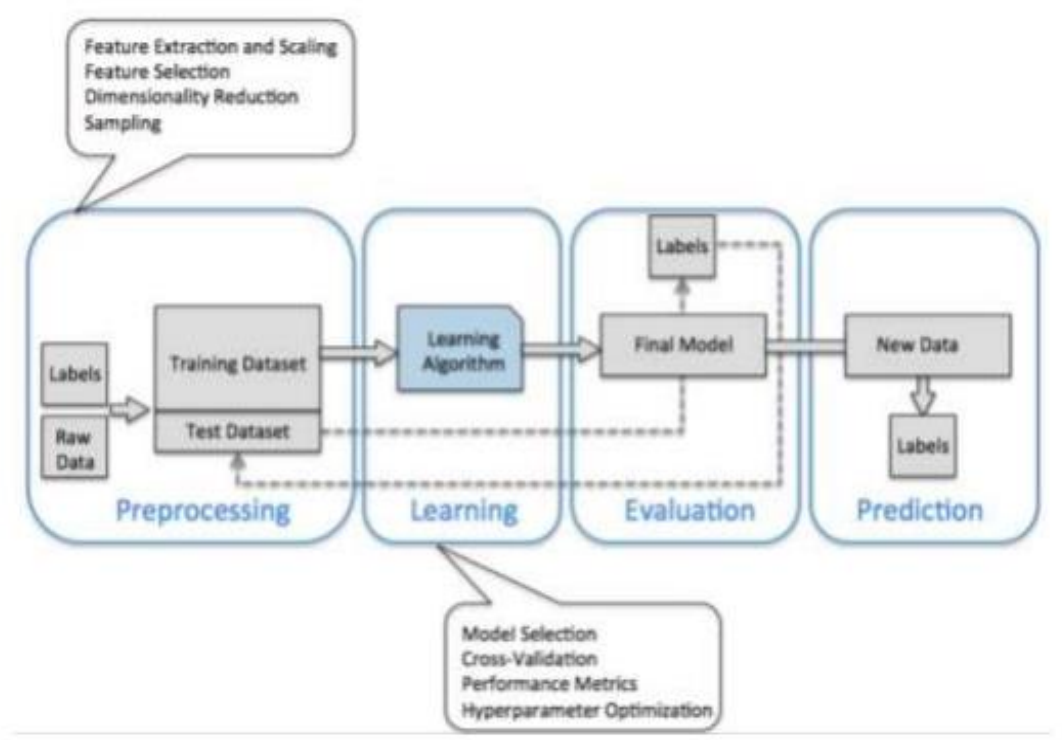

Sumber: (Raschka, 2015)

Gambar 2. Tahapan Klasifikasi

Dari gambar 2 dapat dijelasakan prosesnya, diantaranya pre-processing, learning atau training, validation dan prediction. Pre-processing pada tahapan ini adalah mengelompokan data dengan membagi data menjadi training, validasi dan data untuk tes. Training ada digunakan untuk menentukan bobot (w), validasi data dalam penelitian data adalah untuk parameter tuning sedangkan data tes dalah untuk memvalidasi apakah model yang telah dibangung sudah optimal. Learning atau training dilakukan dengan menciptakan model untuk membuat pola dengan mempelajari data. Untuk melakukan prediktif harus melakukan training data menggunakan algoritma machine learning, dimana algoritma pembelajaran yang dipakai adalah Artificial Neural Network. Validation yaitu dengan mengevaluasi model yang telah diciptakan pada tahap learning dan training. Memastikan bahwa model prediktif sesuai dengan data dan model siap untuk digunakan. Prediction pada tahap ini adalah model yang telah didapatkan untuk memprediksi tes data

\subsection{Instrumen penelitian}

Penelitian ini menggunakan rubric untuk evaluasi tool e-learning dalam artikel (Anstey \& Watson, 2018) untuk menentukan kriteria aplikasi e-leanring yang sesuai untuk online elearning. Instrument penelitian ditunjukan pada tabel 1.

Tabel 1 Instrumen Penelitian

\begin{tabular}{cll}
\hline Dimensi & \multicolumn{1}{c}{ Indikator } & \multicolumn{1}{c}{ Pernyataan } \\
\hline \multirow{4}{*}{ Functionality } & Scale. & Menguji skala (Chou, 2014). \\
\cline { 2 - 4 } & Ease of Use & $\begin{array}{l}\text { Aplikasi mudah digunakan } \\
\text { (Dodun et al., 2015). }\end{array}$ \\
\cline { 2 - 4 } & Tech Support $/$ Help & $\begin{array}{l}\text { Sebagai pendukung SDM } \\
\text { (Nawaz \& Zubair Khan, 2012). }\end{array}$ \\
\cline { 2 - 4 } & Availability. & $\begin{array}{l}\text { Mendukung komunikasi (Anstey } \\
\text { \& Watson, 2018). }\end{array}$ \\
\hline
\end{tabular}




\begin{tabular}{|c|c|c|}
\hline Dimensi & Indikator & Pernyataan \\
\hline \multirow{4}{*}{ Accessibilty } & Accessibility Standards & $\begin{array}{l}\text { Aplikasi ada informasi terperinci } \\
\text { (Bühler \& Fisseler, 2007). }\end{array}$ \\
\hline & Accessibility Initiative. & $\begin{array}{l}\text { Tersedia panduan akses (Bühler } \\
\text { \& Fisseler, 2007). }\end{array}$ \\
\hline & User-Focused Participation & $\begin{array}{l}\text { user dapat berpartisipasi } \\
\text { diplatform yang sama (Phipps \& } \\
\text { Kelly, 2006) }\end{array}$ \\
\hline & Required Equipment & Fasilitas lengkap (Kisworo, 2016) \\
\hline \multirow{3}{*}{ Technical } & Learning Management System & $\begin{array}{lcc}\text { Software } & \text { terintegerasi } & \text { (Prof. } \\
\text { Indira \& MS. Sakhi, 2017). } & \end{array}$ \\
\hline & $\begin{array}{l}\text { Desktop/Laptop Operating } \\
\text { Systems and Browser }\end{array}$ & $\begin{array}{l}\text { Aplikasi bisa berjalan di pc atau } \\
\text { mobile (Kumar Basak, Wotto, \& } \\
\text { Bélanger, 2018). }\end{array}$ \\
\hline & Additional Downloads & $\begin{array}{l}\text { Tersedia fitur download (Baidawi } \\
\text { \& Sandi, 2013). }\end{array}$ \\
\hline \multirow[t]{3}{*}{ Mobile Design } & Access & $\begin{array}{l}\text { Dengan mudah dapat melakukan } \\
\text { akses e-learning dengan } \\
\text { perangkat ponsel (Moubayed et } \\
\text { al., 2018). }\end{array}$ \\
\hline & Functionality & $\begin{array}{l}\text { Semua fitur berfungsi dengan } \\
\text { baik (Chen \& He, 2013). }\end{array}$ \\
\hline & Offline Access & $\begin{array}{l}\text { Aplikasi dapat diakses secara } \\
\text { offline (Akcaoglu \& Lee, 2016) }\end{array}$ \\
\hline \multirow{3}{*}{$\begin{array}{c}\text { Privacy, Data Protection, and } \\
\text { Rights }\end{array}$} & Sign Up / Sign In & $\begin{array}{l}\text { Terdapat login dan registrasi } \\
\text { yang kuat (Maeda \& Ono, 2019). }\end{array}$ \\
\hline & Data Privacy and Ownership & $\begin{array}{l}\text { Aplikasi aman dan menjaga } \\
\text { integritas (Richardson et al., } \\
\text { 2015) }\end{array}$ \\
\hline & $\begin{array}{l}\text { Archiving, Saving, } \\
\text { Exporting Data }\end{array}$ & $\begin{array}{l}\text { Pengguna dapat mengarsipkan, } \\
\text { menyimpan, atau mengimpor dan } \\
\text { mengekspor data (Rapanta, } \\
\text { Botturi, Goodyear, Guàrdia, \& } \\
\text { Koole, 2020). }\end{array}$ \\
\hline \multirow{3}{*}{ Social Presence } & Collaboration & $\begin{array}{l}\text { Pengguna dapat kolaborasi. } \\
\text { (Gregory \& Bannister-Tyrrell, } \\
\text { 2017). }\end{array}$ \\
\hline & User Accountability. & $\begin{array}{l}\text { Tersedia fitur group kelas } \\
\text { (Akcaoglu \& Lee, 2016). }\end{array}$ \\
\hline & Diffusion & $\begin{array}{l}\text { Ada jalur untuk komunikasi } \\
\text { (Akcaoglu \& Lee, 2016). }\end{array}$ \\
\hline \multirow{3}{*}{ Teaching Presence } & Facilitation & $\begin{array}{l}\text { Tersedia fasilitas diskusi. } \\
\text { (Richardson et al., 2015). }\end{array}$ \\
\hline & Customization & $\begin{array}{l}\text { Tersedia fitur perubahan } \\
\text { (Rapanta et al., 2020). }\end{array}$ \\
\hline & Learning Analytics & $\begin{array}{l}\text { Tersedia fitur untuk evaluasi } \\
\text { (Rapanta et al., 2020). }\end{array}$ \\
\hline \multirow[t]{2}{*}{ Cognitive Presence } & $\begin{array}{l}\text { Enhancement of Cognitive } \\
\operatorname{Task(s)}\end{array}$ & $\begin{array}{l}\text { Tersedia untuk menilai kognisi } \\
\text { (Gregory \& Bannister-Tyrrell, } \\
\text { 2017). }\end{array}$ \\
\hline & Higher-Order Thinking & $\begin{array}{l}\text { Aplikasi dapat menjadi inspirasi } \\
\text { (Lee, 2014). }\end{array}$ \\
\hline
\end{tabular}

\subsection{Teknik Pengumpulan Data}

Penelitian ini menggunakan angket yang dikirim menggunakan google form kepada mahasiswa dan dosen dilingkungan univeristas bhayangkara Jakarta Raya. Angket berisikan pertanyaan mengenai function Accessibility, technical, mobile design, Privacy, Data Protection, Social Presence, Teaching Presence, Cognitive Presence pada beberapa aplikasi e-learning 
yang digunakan. Didalam kuisioner digunakan skala linkert untuk masing-masing responden. Kriteria penilaian responden dapat dilihat pada table 2 .

Tabel 2. Bobot Jawaban Responden

\begin{tabular}{lc}
\multicolumn{1}{c}{ Jawaban } & Nilai \\
\hline Tidak ada & 1 \\
\hline Ragu-Ragu & 2 \\
\hline Ada & 3 \\
\hline
\end{tabular}

Sumber: Hasil Pengolahan Data (2021)

\section{Hasil dan Pembahasan}

\subsection{Profil Data}

Adapun data frekuensi hasil kuesioner yang didapat dari 197 sampel penelitian untuk mengukur aplikasi slack,moodle,google class room dan Edmodo. Sehingga dari hasil kuisioner digunakan untuk dataset, dimana setiap indicator dijadikan sebagai variable untuk input. Untuk variabel yang digunakan dalam penelitian ini dapat dilihat pada tabel 3 .

Table 3. Percobaan penggunaan Hidden Layer

\begin{tabular}{cl}
\hline Variabel & \multicolumn{1}{c}{ Keterangan } \\
\hline $\mathrm{X} 1$ & Scale \\
\hline $\mathrm{X} 2$ & Ease of Use \\
\hline $\mathrm{X} 3$ & Tech Support \\
\hline $\mathrm{X} 4$ & Hypermediality \\
\hline $\mathrm{X} 5$ & Accessibility Standards \\
\hline $\mathrm{X} 7$ & Accessibility Initiative \\
\hline $\mathrm{X} 8$ & Pser Focused \\
\hline $\mathrm{X} 9$ & Required Equipment \\
\hline $\mathrm{X} 10$ & Learning Management System \\
\hline $\mathrm{X} 11$ & Dekstop/Laptop OS Browser \\
\hline $\mathrm{X} 12$ & Additional Downloads \\
\hline $\mathrm{X} 13$ & Access \\
\hline $\mathrm{X} 14$ & Fuctionality \\
\hline $\mathrm{X} 15$ & Offline Acess \\
\hline $\mathrm{X} 16$ & Sign up/ Sign In \\
\hline $\mathrm{X} 17$ & Data Privacy \\
\hline $\mathrm{X} 18$ & Archiving, saving and Exporting \\
\hline $\mathrm{X} 19$ & Data \\
\hline $\mathrm{X} 20$ & Collaboration \\
\hline $\mathrm{X} 21$ & Disffusion Accountability \\
\hline $\mathrm{X} 22$ & Facilitation \\
\hline $\mathrm{X} 23$ & Customization \\
\hline $\mathrm{X} 24$ & Learning Analytics \\
\hline $\mathrm{X} 25$ & Enhancement Cognitive Task \\
\hline $\mathrm{X} 26$ & Higher-Order Thinking \\
\hline $\mathrm{Y}$ & Metacognitive \\
\hline $\mathbf{2 0 2 1 )}$ & Target \\
\hline Sumber: Hasil Pengolahan Dat \\
\hline
\end{tabular}

\subsection{Mendefinisikan Input dan Target}

Untuk input data yang akan diolah oleh algoritma ANN menggunakan 27 variabel $x$ yang sudah didefinisikan tahap sebelumnya. Sedangkan untuk mendefinisikan target Hasil yang diharapakan dari penelitian ini adalah rekomendasi aplikasi e-learning yang tepat dengan memprediksi dari data yang telah didapatkan. Hasil yang dimaksudkan adalah Jika target 
bernilai 0 berarti aplikasi tidak direkomendasikan sedangkan Jika target bernilai 1 berarti aplikasi direkomendasikan

\subsection{Prepocessing}

Pada tahap persiapan ini pengolahan data menggunakan Microsoft excel, menghitung data hasil kuisioner, selanjutnya untuk digunakan untuk kebutuhan pengolahan algoritam didalam pemograman python file disimpan dengan format csv. Dimana dalam tahapan ini data di import untuk dijadikan data array dan dataframe menggunakan library machine learning numpy dan pandas. Untuk tahapan preprocessing yang diolah menggunkan python dapat dilihat listing program pada gambar 3 .

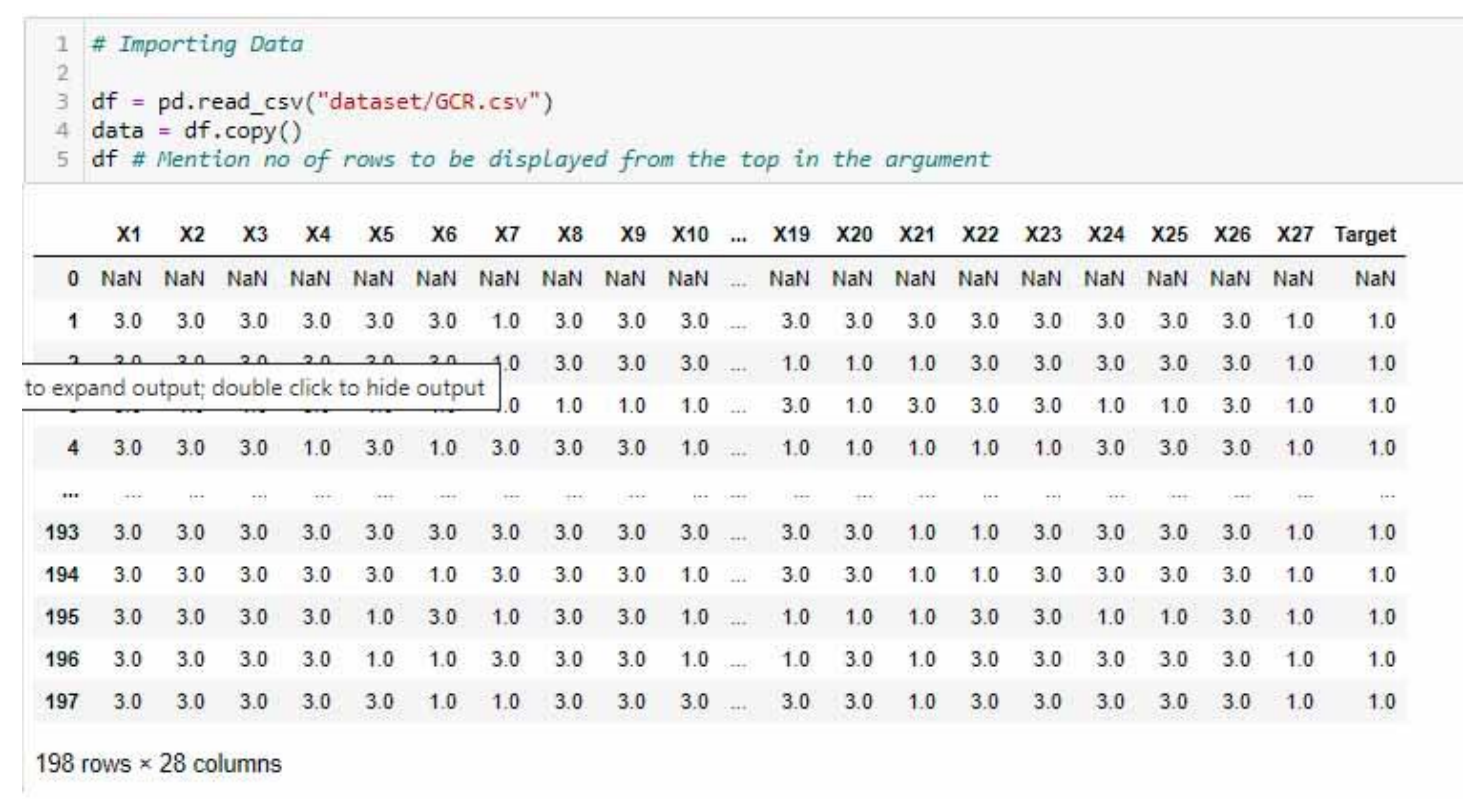

Sumber: Hasil Penelitian (2021)

\section{Gambar 3. Tahap Prepocessing}

\subsubsection{Pemilihan data}

Pada proses pemilihan data adalah memisahkan variabel dengan target, disini attribute $\mathrm{x} 1$ sampai $\mathrm{x} 27$ adalah variabel $\mathrm{X}$ sedangkan attribute Target adalah variabel y sebagai output. Listing program untuk pemilihan data ditunjukan pada gambar 4.

\section{In [7]: $1 X=d f . i l o c[:, 0: 27]$ $2 y=d f . i l o c[:, 27]$}

Sumber: Hasil Penelitian (2021)

Gambar 4. Listing Program Untuk Pemilihan Data

\subsubsection{Feature Extraction}

Dalam proses krasifikasi algoritma pembelajaran membutuhkan pemisahan data yang bertujuan untuk mencocokan data sample kepada class/label tertentu (Raschka, 2015). Listing program python untuk Proses pemisahan ditunjukan pada gambar 5 . 
\# Splitting the dotoset into the Troining set and Test set

fron sklearn, model selection import train test split

$X_{-}$train, $X_{-}$test, $y_{-}$train, $y_{-}$test $=$train test split $\left(X_{1}, y_{\text {, test }}\right.$ size $=0.2$, random state $\left.=0\right)$

Sumber: Hasil Penelitian (2021)

Gambar 5. Listing Program untuk Feature Extraction

Dari gambar 5 pemisahan data training dimulai dengan import library machine learning sklearn_model_selection. Data training dengan variable X_train, target adalah y_train dan untuk uji model menggunakan $\mathrm{x} \_$test dan y_test.

\subsubsection{Feature Scalling}

Data yang diinput hasil dari kuisioner menunjukan nilai angka 1 sampai 3 . Pada tahapan ini adalah proses normalisasi untuk mendapatkan nilai standar deviasi yang tidak bervariasi. Rentan nilai yang bervariasi akan mengakibatkan error dalam yang tinggi, algoritma learning akan melakukan pembelajaran dengan mepioritaskan error rendah (Raschka, 2015). Gambar 6 adalah proses melakukan feature scalling.

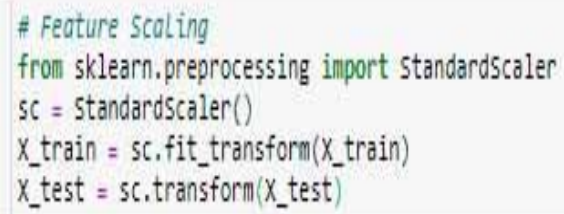

Sumber: Hasil Penelitian (2021)

Gambar 6. Listing Program Untuk Feature Scalling

\subsubsection{Training, Validation, Test Split}

Pada tahapan ini adalah menentukan nilai training dari jumlah data 197 sample digunakan untuk proses training adalah sebanyak 105 sample, untuk test sebanyak 42 sample dan validasi adalah 52 sample dimana prosesnya dilakukan secara random. Proses training, validation dan test split dalam python dapat dilihat pada gambar 4 .

\subsection{Learning}

Pada tahapan ini data hasil pembejaran dilakukan dengan algoritma pembelajaran ditampilkan. Tahapan ini mempelajari dengan melakukan training data untuk menghasilkan akurasi dalam memprediksi aplikasi yang tepat untuk digunakan dalam e-learning. Berikut tahapan metode dalam learning.

\subsubsection{Training, Validation, Test Split}

Kriteria untuk membangun pembelajaran dengan nerural network adalah menggunkan Input layer sebanyak 27 neuron, output layer sebanyak 1 neuron, fungsi aktivasi hidden layer menggunakan relu, fungsi aktivasi untuk output adalah sigmoid. Parameter untuk melakukan training melakukan beberapa percobaan dalam membangun arsitektur artificial Neural Network 
(ANN) dengan menginput beberapa neuron. Berikut tablel 4 menampung hasil percobaan menggunakan neuron.

Table 4. Percobaan menggunakan beberapa Neuron

\begin{tabular}{cc}
\hline Jumlah Neuron & Accuracy \\
\hline 10 & $96 \%$ \\
\hline 15 & $95 \%$ \\
\hline 20 & $100 \%$ \\
\hline 50 & $85 \%$ \\
\hline
\end{tabular}

Sumber: Hasil Pengolahan Data (2021)

Dari tabel 4 akurasi tertinggi yang dihasilkan dalam penelitian ini adalah jumlah neuron. Selanjutnya melakukan percobaan dengan menggunakan beberapa hidden layer. Percobaan penggunaan hidden layer dapat dilihat pada tabel 5 .

Table 5. Percobaan penggunaan Hidden Layer

Sumber: Hasil Pengolahan Data $\overline{(2021)}$

\begin{tabular}{cc}
\hline Jumlah Hidden Layer & Training Accuracy \\
\hline 2 & $94,29 \%$ \\
\hline 3 & $97,6 \%$ \\
\hline 4 & $91,8 \%$ \\
\hline
\end{tabular}

Dari hasil percobaan yang tampak pada tabel 5 menunjukan arsitektur ANN yang memilikan nilai training tertinggi adalah menggunakan 3 hidden layer dengan akurasi $97.6 \%$. Untuk membangun deep learning menggunakan neural network dalam penelitian ini adalah menggunakan pemograman python dimana ANN jenis deep learning membutuhkan library keras. Berikut list program dapat dilihat pada gambar 7 .

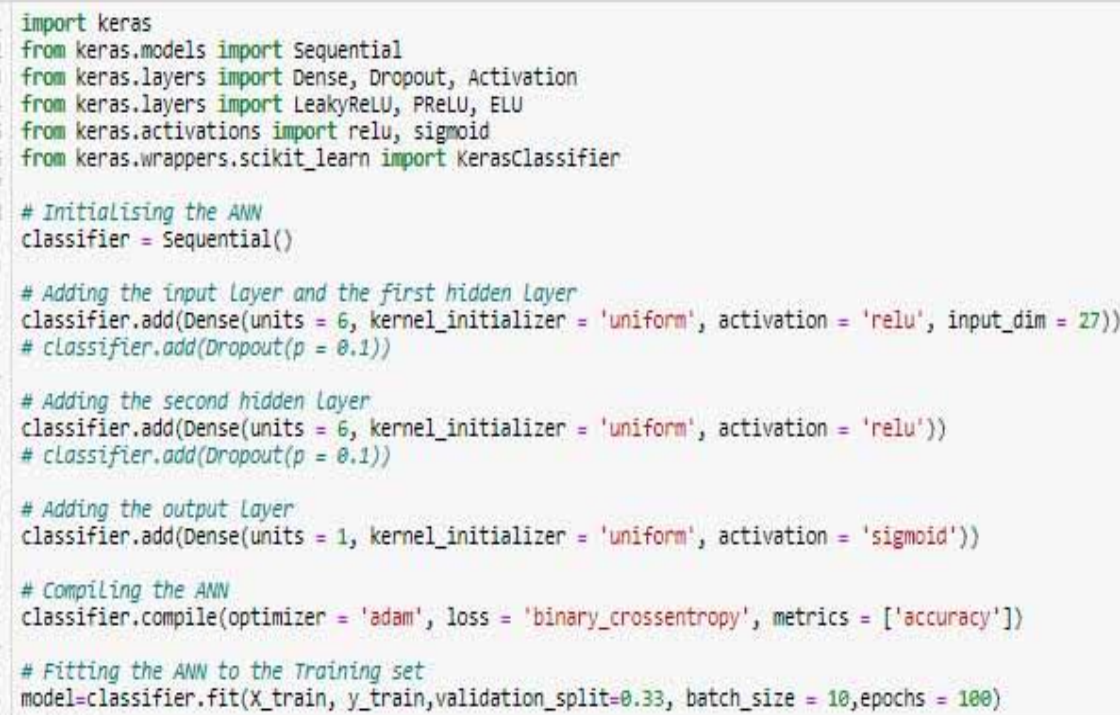

umber: Hasil Pengelohan Data(2021)

Gambar 7. Listing Program Untuk Membangun Model ANN

Hasil yang didapatkan setelah menjalankan listing diatas adalah didapatkan accuracy tertinggi 0.9429 atau $94.29 \%$ untuk fase learning training.

\subsection{Evaluation}

Pada evaluation adalah melakukan evaluasi dari beberapa parameter yang digunakan untuk mencapai hasil maximal untuk memprediksi aplikasi e-learning yang direkomendasikan. 
Parameter yang diuji adalah percobaan penggunaan Dropout, hasil dari percobaan penggunaan beberapa Dropout dapat dilihat pada table 6 .

Table 6. Percobaan penggunaan beberapa Dropout

\begin{tabular}{cc} 
Dropout & Validasi Accuracy \\
\hline 0.1 & 0.9231 \\
\hline 0.01 & 0.943 \\
\hline 0.001 & 0.924 \\
\hline
\end{tabular}

Sumber: Hasil Pengolahan Data (2021)

Hasil didapatkan sesuai yang tampak pada tabel 6 adalah drop out dengan nilai 0.01 memilik validasi tertinggi. Parameter lengkap untuk membangun ANN terbaik dengan epoch, 100, optimize: adam, Dropout: 0.01, Loss function: binary_crossentropy dan Batch size: 128.

\subsection{Prediction}

Tahap akhir dari ANN adalah prediksi, hasil yang didapatkan berupa klasifikasi hasil akhir dari tes data yang telah dilakukan learning. Berikut listing program untuk prediksi dapat dilihat pada gambar 8.

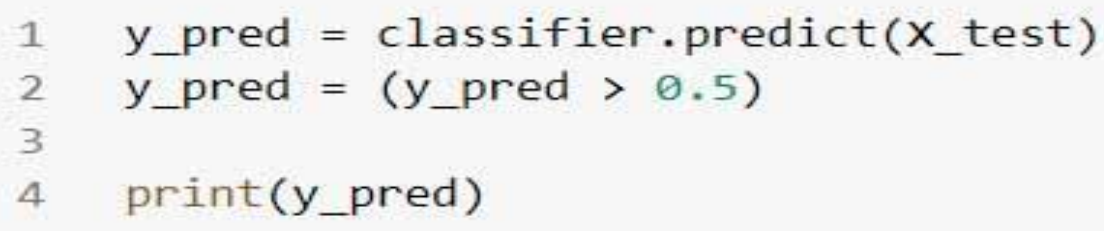

Sumber: Hasil Pengelohan Data (2021)

Gambar 8. Listing Program Untuk Prediksi

Dari hasil learning dilanjutkan dengan menggunakan confusion matrix untuk menguji akurasi dari hasil learning. Hasil ditunjukan pada gambar 9, dimana hasil selama learning banyak terjadi error karena itu saat uji confusion matrix mendapatkan 4 data yang ditampung dalam matrix.

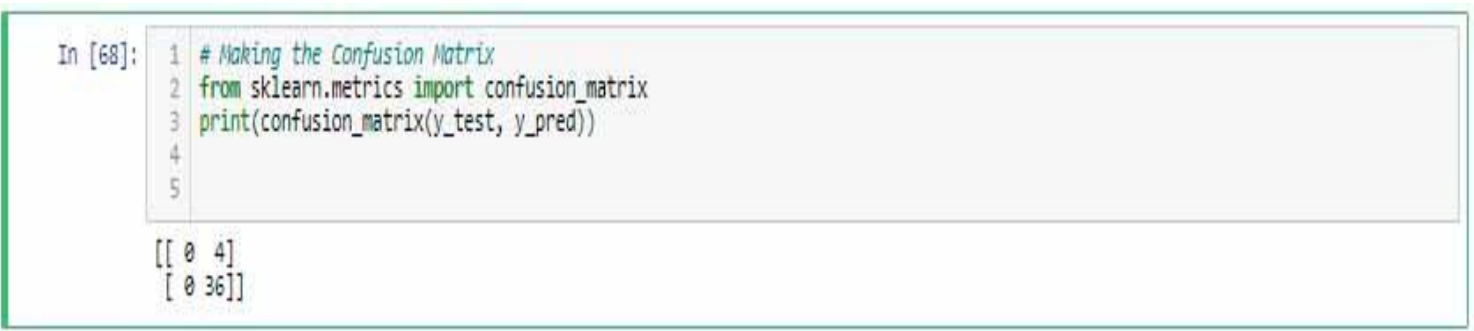

Sumber: Hasil Pengelohan Data(2021)

\section{Gambar 9. Listing Program Untuk Menguji Confusion Matrix}

Untuk mendapatkan gambaran hasil prediksi berdasarkan uji confusion matrik visualisasiskan menggunakan grafik pada gambar 10 . 


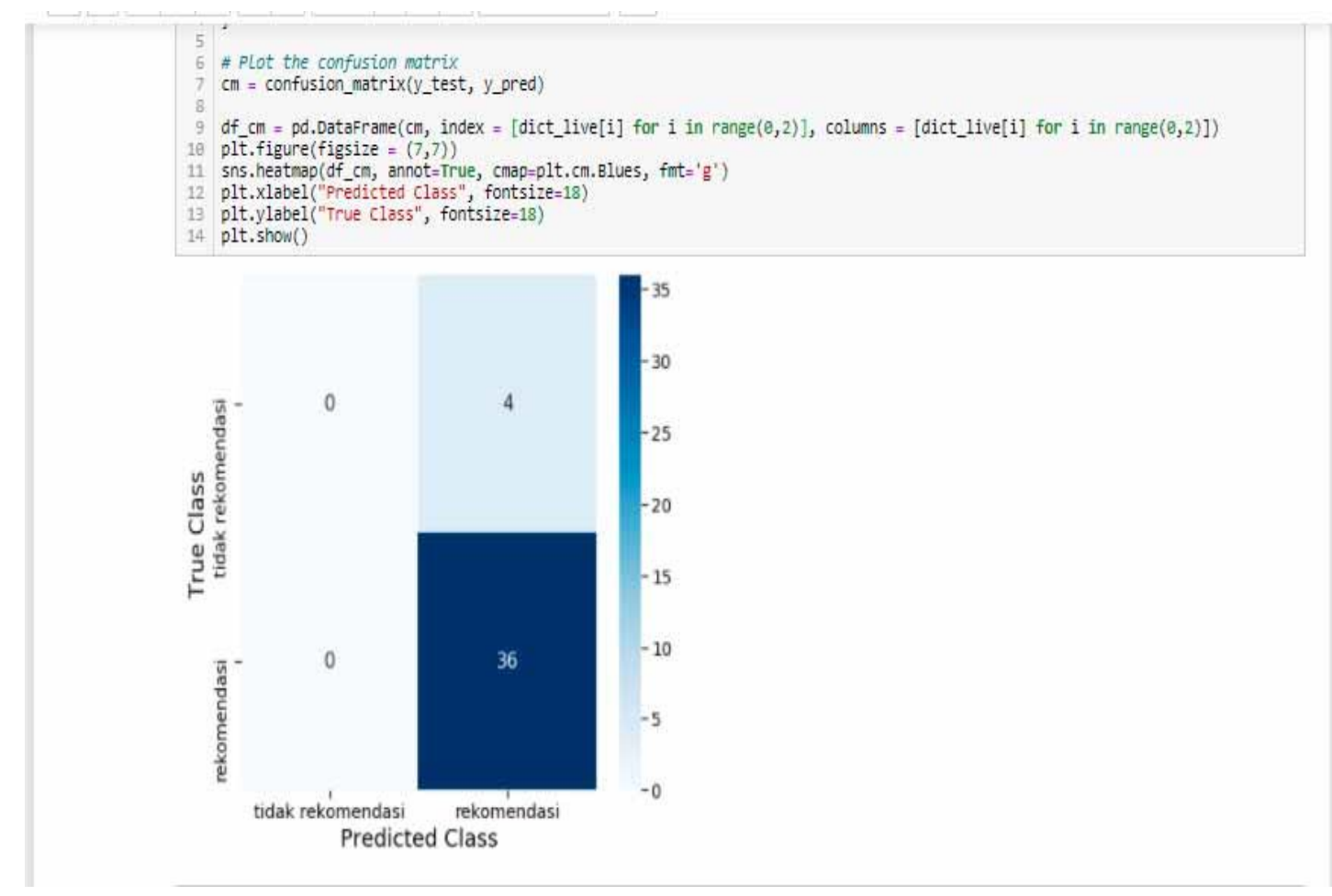

Sumber: Hasil Pengelohan Data(2021)

Gambar 10. Listing Program Untuk Menguji Confusion Matrix

Dari gambar 10 menunjukan tidak rekomendasi 0 dan rekomendasi 36 jadi data valid dan model ANN bias digunakan untuk melakukan prediksi.

\subsection{Hasil implementasi Deep Learning}

Setelah dilakukan proses learning dalam implementasi Deep Learning menggunakan algoritma ANN untuk implementasi e-learning dari data kuisioner yang telah di proses. Hasil prediksi untuk rekomendasi aplikasi e-learning yang tepat digunakan untuk pembelajaran online berdasarkan nilai akurasi yang didapatkan dari setiap aplikasi e-learning. Berikut listing program untuk melihat hasil akurasi aplikasi ditunjukan pada gambar 11.

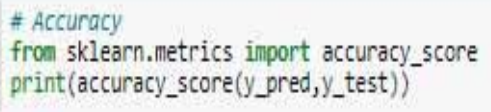

Sumber: Hasil Pengelohan Data(2021)

Gambar 11. Listing Program accuracy

Hasil accuracy untuk setiap aplikasi e-learning dapat dilihat pada tabel 5 .

Tabel 7. Hasil Accuracy Aplikasi E-learning

\begin{tabular}{lll}
\hline \multicolumn{1}{c}{ Aplikasi } & \multicolumn{1}{c}{ Accuracy } \\
\hline Moodle & $97,5 \%$ & \\
\hline Google Classroom & $87 \%$ & \\
\hline Edmodo & $90,5 \%$ \\
\hline Slack & $75.5 \%$ & \\
\hline
\end{tabular}

Sumber: Hasil Pengolahan Data (2021) 
Dari tabel 7 menunjukan bahwa accuracy yang dihasilkan oleh aplikasi moodle lebih tinggi disbanding aplikasi e-learning lainnya, maka itu rekomendasi aplikasi e-learning yang tepat digunakan adalah aplikasi moodle.

\section{Kesimpulan}

Adapun kesimpulan dalam penelitian ini adalah untuk mengukur efektivitas aplikasi $e$ learning yang digunakan mengambil data dari pihak universitas aplikasi e-learning yang sering digunakan dimana pengambilan data untuk mengambil dataset dilakukan dengan menyebar kuisioner kepada dosen dan mahasiswa sehingga menghasilkan prediksi untuk rekomendasi aplikasi e-learning yang tepat setelah dilakukan pembelajaran menggunakan algoritma Artifical Neural Network untuk deep learning maka dihasilkan aplikasi moodle dengan akurasi $97 \%$ terpilih sebagai rekomendasi aplikasi yang akan digunakan di perguruan tinggi.

\section{Ucapan Terima Kasih}

Ucapan Terima kasih kepada LPPMP Universitas Bhayangkara yang telah mendanai riset penelitian ini sehingga dapat selesai tepat waktu

\section{Daftar Pustaka}

Akcaoglu, M., \& Lee, E. (2016). Increasing social presence in online learning through small group discussions. International Review of Research in Open and Distance Learning, 17(3), 1-17. https://doi.org/10.19173/irrodl.v17i3.2293

Anstey, L. M., \& Watson, G. P. L. (2018). A Rubric for Evaluating E-Learning Tools in Higher Education.

Baidawi, T., \& Sandi, M. (2013). Desktop Computing Dengan Metode Eyeos. Seminar Nasional Inovasi Dan Teknologi (SNIT) 2013 IMPLEMENTASI, (May), A-221.

Bühler, C., \& Fisseler, B. (2007). Accessible E-Learning and Educational Technology Extending Learning Opportunities for People with Disabilities. Conference ICL2007, September 26 -28, 2007, (August 2014), 11 pages. Retrieved from https://hal.archivesouvertes.fr/hal-00257138/

Chauhan, K., \& Ram, S. (2018). Image Classification with Deep Learning and Comparison between Different Convolutional Neural Network Structures using Tensorflow and Keras. International Journal of Advance Engineering and Research Development, 5(02), 533538.

Chen, Y., \& He, W. (2013). Security risks and protection in online learning: A survey. International Review of Research in Open and Distance Learning, 14(5), 108-127. https://doi.org/10.19173/irrodl.v14i5.1632

Chou, T.-C. R. (2014). A Scale of University Students' Attitudes toward e-Learning on the Moodle System. International Journal of Online Pedagogy and Course Design, 4(3), 4965. https://doi.org/10.4018/ijopcd.2014070104 
Dodun, O., Panaite, E., Seghedin, N., Nagîţ, G., Duşa, P., Neştian, G., \& Slətineanu, L. (2015). Analysis of an E-learning Platform use by Means of the Axiomatic Design. Procedia CIRP, 34, 244-249. https://doi.org/10.1016/j.procir.2015.07.059

Fakhfakh, R., Ben, A., \& Ben, C. (2017). Deep Learning-Based Recommendation: Current Issues and Challenges. International Journal of Advanced Computer Science and Applications, 8(12). https://doi.org/10.14569/ijacsa.2017.081209

Gregory, S., \& Bannister-Tyrrell, M. (2017). Digital learner presence and online teaching tools: higher cognitive requirements of online learners for effective learning. Research and Practice in Technology Enhanced Learning, 12(1). https://doi.org/10.1186/s41039-0170059-3

Kisworo, M. W. (2016). Implementing open source platform for education quality enhancement in primary education: Indonesia experience. Turkish Online Journal of Educational Technology, 2016(july), 295-301.

Kumar Basak, S., Wotto, M., \& Bélanger, P. (2018). E-learning, M-learning and D-learning: Conceptual definition and comparative analysis. E-Learning and Digital Media, 15(4), 191216. https://doi.org/10.1177/2042753018785180

Lee, S. M. (2014). The relationships between higher order thinking skills, cognitive density, and social presence in online learning. Internet and Higher Education, 21, 41-52. https://doi.org/10.1016/j.ineduc.2013.12.002

Liu, J., \& WU, C. (2017). Deep Learning Based Recommendation: A Survey. Lecture Notes in Electrical Engineering, 2(March 2017), 467-475. https://doi.org/10.1007/978-981-10-41549

Maeda, M., \& Ono, Y. (2019). Diffusion of lesson study as an educational innovation. International Journal of Comparative Education and Development, 21(1), 46-60. https://doi.org/10.1108/IJCED-10-2018-0044

Moubayed, A., Injadat, M., Nassif, A. B., Lutfiyya, H., \& Shami, A. (2018). E-Learning: Challenges and Research Opportunities Using Machine Learning Data Analytics. IEEE Access, 6, 39117-39138. https://doi.org/10.1109/ACCESS.2018.2851790

Muniasamy, A., \& Alasiry, A. (2020). Deep learning: The impact on future eLearning. International Journal of Emerging Technologies in Learning, 15(1), 188-199. https://doi.org/10.3991/IJET.V15I01.11435

Nawaz, A., \& Zubair Khan, M. (2012). Issues of Technical Support for e-Learning Systems in Higher Education Institutions. International Journal of Modern Education and Computer Science, 4(2), 38-44. https://doi.org/10.5815/ijmecs.2012.02.06

Phipps, L., \& Kelly, B. (2006). Holistic approaches to e-learning accessibility. Alt-J, 14(1), 6978. https://doi.org/10.1080/09687760500479860

Prof. Indira, D., \& MS. Sakhi. (2017). Online learning. International Education \& Research Journal [IERJ], 3(8), 32-34. https://doi.org/10.4324/9780429355097-7

Rapanta, C., Botturi, L., Goodyear, P., Guàrdia, L., \& Koole, M. (2020). Online University 
Teaching During and After the Covid-19 Crisis: Refocusing Teacher Presence and Learning Activity. Postdigital Science and Education, 2(3), 923-945. https://doi.org/10.1007/s42438-020-00155-y

Raschka, S. (2015). Python Machine Learning. Birmingham: Packt Publishing Limited.

Reza, R. (2017). Penerapan Jaringan Saraf Tiruan Jenis Deep Learning Untuk Sistem Informasi Kesehatan Jembatan. Universitas Bina Nusantara.

Richardson, J. C., Koehler, A. A., Besser, E. D., Caskurlu, S., Lim, J. E., \& Mueller, C. M. (2015). Conceptualizing and investigating instructor presence in online learning environments. International Review of Research in Open and Distance Learning, 16(3), 256-297. https://doi.org/10.19173/irrodl.v16i3.2123

Shiddieqy, H. A., Hariadi, F. I., \& Adiono, T. (2017). Implementation of deep-learning based image classification on single board computer. 2017 International Symposium on Electronics and Smart Devices, ISESD 2017, 2018-Janua, 133-137. https://doi.org/10.1109/ISESD.2017.8253319 